\title{
Functional properties of a Brazilian derived mouse embryonic stem cell line
}

\author{
LEANDRO VAIRO, EMILIANO MEDEI, DANÚBIA S. DOS SANTOS, DEIVID C. RODRIGUES, \\ REGINA C.S. GOLDENBERG and ANTONIO C. CAMPOS DE CARVALHO
}

Instituto de Biofísica Carlos Chagas Filho, Universidade Federal do Rio de Janeiro, Bloco G-CCS, Cidade Universitária, Ilha do Fundão, 21949-900 Rio de Janeiro, RJ, Brasil

Manuscript received on September 16, 2014; accepted for publication on November 28, 2014

\begin{abstract}
Pluripotent mouse embryonic stem cells (mESC) are cell lines derived from the inner cell mass of blastocyst-stage early mammalian embryos. Since ion channel modulation has been reported to interfere with both growth and differentiation process in mouse and human ESC it is important to characterize the electrophysiological properties of newly generated mESC and compare them to other lines. In this work, we studied the intercellular communication by way of gap junctions in a Brazilian derived mESC (USP-1, generated by Dr. Lygia Pereira's group) and characterized its electrophysiological properties. We used immunofluorescence and RT-PCR to reveal the presence of connexin 43 (Cx43), pluripotency markers and ion channels. Using a co-culture of neonatal mouse cardiomyocytes with $\mathrm{mESC}$, where the heart cells expressed the enhanced Green Fluorescent Protein, we performed dye injections to assess functional coupling between the two cell types observing dye diffusion. The patch-clamp study showed outward currents identified as two types of potassium currents, transient outward potassium current (Ito) and delayed rectifier outward potassium current (Iks), by use of specific drug blockage. Calcium or sodium currents in undifferentiated mESC were not identified. We conclude that USP-1 mESC has functional Cx43 channels establishing intercellular communication among themselves and with cardiomyocytes and has a similar electrophysiological profile compared to other mESC cell lines.
\end{abstract}

Key words: $\mathrm{Cx} 43$ channels, electrophysiological properties, gap junctions, mouse embryonic stem cells.

\section{INTRODUCTION}

Pluripotent mouse embryonic stem cells (mESC) are cell lines derived from the inner cell mass of blastocyst-stage early mammalian embryos. These unique cells can self-renew while maintaining their pluripotency and differentiate into cellular derivates of all three primary germ layers in vivo or under appropriate cultivation in vitro (Evans

Correspondence to: Antonio Carlos Campos de Carvalho E-mail: acarlos@biof.ufrj.br and Kaufman 1981, Martin 1981) providing an unlimited source of cells for cell-based therapies.

Although mESCs from different lineages have been shown to share a number of basic similarities they may differ slightly in properties related to growth and differentiation capacity (Lee et al.2005). Since ion channel modulation has been reported to interfere with both processes in mouse and human ESC and induced pluripotent stem cells (iPSC) (Wang et al. 2005, Morokuma et al. 2008, 
Jiang et al. 2010) it is important to characterize the electrophysiological properties of newly generated mESC and compare them to other lines.

There are hundreds of different ion channels and they are distinguished based upon their ion selectivity, gating mechanism, and sequence dissimilarity (Hille 2001). Previous reports have described the presence of potassium, but not sodium or calcium channels in mouse and human ESC (Wang et al. 2005). In contrast, Sartiani et al. (2007) described the presence of both potassium and calcium currents in human ESC (hESC), but Jiang et al. (2010) could only find potassium currents and not calcium currents in hiPSC. These differences highlight the importance of characterizing the electrophysiological properties of pluripotent stem cells before differentiation and usage in in vitro or in vivo experimental models.

Gap junctions are ion channels formed by the docking and opening of two hemi-channels in the apposed membranes of adjacent cells. Each hemichannel is composed of six protein subunits termed connexins. To date, 20 connexin isoforms have been found in the mouse genome, and 21 in the human (Söhl and Willecke 2003). Although brief reports of connexin expression by mouse (Oyamada et al. 1996) and human (Bhattacharya et al. 2004, Richards et al. 2004, Carpenter et al. 2004) ESC have appeared, the properties of undifferentiated mESC gap junction intercellular communication (GJIC), have not been characterized.

\section{MATERIALS AND METHODS}

In this study, we describe the electrophysiological profile of a new mouse embryonic cell line, USP1 , generated in Brazil. We investigate the presence of voltage gated and gap junction channels in these cells using different methodologies. All procedures were carried out according to the international practices for animal use and care under the control of an internal committee of the Universidade Federal do Rio de Janeiro, Brazil under number IBCCF-26.
EMBRYONIC STEM CELl CULTURE

The mouse embryonic stem cell (mESC) line USP-1 was derived from the inner cell mass of mouse blastocists (Sukoyan et al. 2002) and kindly donated by Professor Lygia Pereira from the University of São Paulo - Brazil. This cell line was grown in high glucose $(4.5 \mathrm{~g} / \mathrm{L})$ Dulbecco's modified Eagle's medium (DMEM), supplemented with 20\% fetal bovine serum (Gibco), 2mM L-glutamin, $50 \mathrm{U} / \mathrm{mL}$ penicillin, $50 \mu \mathrm{g} / \mathrm{mL}$ streptomycin, $0.1 \mathrm{mM}$ $\beta$-mercaptoethanol (Sigma), and $1000 \mathrm{U} / \mathrm{mL}$ leukaemia inhibitory factor (LIF) (ESGRO-LIF, Chemicon) in $0.1 \%$ gelatin-coated dishes with feeder layer cells at $37{ }^{\circ} \mathrm{C}$ in humidified air with $5 \% \mathrm{CO}_{2}$. As feeder layer cells, mouse embryonic fibroblasts (MEF) were cultured in the same medium of mESC, supplemented with $10 \%$ fetal bovine serum (Gibco) and were mitotically inactivated for 3h with $10 \mu \mathrm{g} / \mathrm{ml}$ mitomycin C (Sigma). For the experiments here reported, $\mathrm{mESC}$ cells were grown for a maximum of 35 passages in the presence of feeder layer cells and LIF.

\section{PRIMARY CULTURES OF CARDIOMYOCYTES}

Neonatal mice which expressed enhanced Green Fluorescent Protein (eGFP-transgenic C57/BL6 mice) were killed by decapitation, and the hearts were isolated and placed in $60 \mathrm{~mm}$ plastic culture dishes containing sterile ice-cold Dulbecco's phosphate-buffered saline (PBS; GIBCO-BRL). After rinsing with PBS to remove the blood, we thoroughly minced the hearts in the dissociation solution [containing $1.25 \%$ pancreatin (GIBCO$\mathrm{BRL}$ ) and $3 \mathrm{mg} / \mathrm{mL}$ of bovine serum albumin (BSA; Sigma, St. Louis, MO) diluted in (in g/100 mL) $8.0 \mathrm{NaCl}, 0.2 \mathrm{KCl}, 0.05 \mathrm{Na}_{2} \mathrm{HPO}_{4}, 1.0 \mathrm{NaHCO}_{3}$, and 2.0 dextrose; $\mathrm{pH}$ 7.1-7.2]. The homogenate was then transferred to a $25 \mathrm{~mL}$ Ehrlenmeyer flask with $5 \mathrm{~mL}$ of the dissociation solution and placed in a water bath $\left(37^{\circ} \mathrm{C}\right)$ for 5 min under continuous stirring. The supernatant fraction containing single cells from each digestion period was collected in 
a conical $15 \mathrm{~mL}$ tube and spun at $400 \times \mathrm{g}$ for 5 min, and the pellet was re-suspended in $1 \mathrm{~mL}$ of Dulbecco's modified Eagle's medium (DMEM) [containing 10\% fetal bovine serum (GIBCO-BRL) and $1 \%$ penicillin/streptomycin (GIBCO-BRL)]. The tube with the dissociated cells was then placed in the incubator $\left(37^{\circ} \mathrm{C}, 5 \% \mathrm{CO}_{2}\right)$. The dissociation procedure was repeated five to seven times or until the heart tissue was totally dissociated. The cells were pooled and preplated in $100 \mathrm{~mm}$ plastic culture dishes for $1 \mathrm{~h}$, to allow the non-muscle cells to attach. Following, the remaining unattached cells, highly enriched in myocytes, were plated $\left(2 \times 10^{5}\right.$ cells $\left./ \mathrm{cm}^{2}\right)$ in glass coverslips $(12 \mathrm{~mm}$ diameter coverslips on 24 well plates), placed in the incubator, and allowed to settle for $24 \mathrm{~h}$. After this period, we washed the flasks with DMEM to remove the non-adherent cells and fed the cells with $0.5 \mathrm{~mL}$ of DMEM containing $10 \mu \mathrm{g} / \mathrm{mL}$ mitomycin C (Sigma) for $3 \mathrm{~h}$ to inhibit fibroblast growth. The cultures were maintained at $37^{\circ} \mathrm{C}$ in a $5 \% \mathrm{CO}_{2}$ humidified incubator. All animal protocols were approved by our institutional animal care and use committee.

\section{Co-Culture}

A co-culture of mESC and eGFP cardiomyocytes was established. $48 \mathrm{~h}$ after initiating the primary culture of cardiomyocytes, $2 \times 10^{4} \mathrm{mESC}$ were plated over them in LIF containing medium and 2 days later colonies were formed and experiments performed.

IMMUNOCYTOCHEMISTRY

Cells were plated on glass coverslips and fixed with $70 \%$ ethanol for $20 \mathrm{~min}$. at $-20^{\circ} \mathrm{C}$ for $\mathrm{Cx} 43$ immunostaining or $4 \%$ paraformaldehyde for $15 \mathrm{~min}$. at room temperature for other proteins immunostaining. In short, cells were first incubated for $30 \mathrm{~min}$. at room temperature with $2 \%$ bovine serum albumin (BSA) to reduce nonspecific binding. Then followed by overnight incubation at $4{ }^{\circ} \mathrm{C}$ with antibodies for $\mathrm{Cx} 43$ (Zymed-710700, diluted 1:100); stage-specific Embryonic antigen 1 (SSEA-1) (Santa Cruz sc-21702, diluted 1:100), octamer-binding transcription factor 4 (OCT3/4) (AbCam ab-19857, diluted 1:500); delayed rectifier outward potassium channel subunit KCNQ1 (IKs channel former) (Santa Cruz sc20816, diluted 1:100); transient outward voltage potassium channel subunit Kv1.4 (Santa Cruz sc16180, diluted 1:100); transient outward voltage potassium channel subunit Kv4.2 (Santa Cruz sc11680, diluted 1:100); transient outward voltage potassium channel subunit Kv4.3 (Santa Cruz sc-11686, diluted 1:100); voltage-gated sodium channel subunit Nav1.5 (AbCam ab56240, diluted 1:200) and calcium voltage channel subunit $\mathrm{Ca} 1 \alpha$ (Santa Cruz sc-16230, diluted 1:100). The cells were incubated for $1 \mathrm{~h}$ at room temperature with secondary antibodies conjugated with Cyanine Dye 3 (Сy3) (Jackson Research 115-165-003 and 111-165-144, diluted 1:1000) or Alexa 488 (Invitrogen A-11001 and A-11008 diluted 1:400). The coverslips were then washed three times for 10 min. each with PBS, the nuclei were stained with diamidino-2-phenylindole dye (DAPI) and coverslips were mounted in medium for fluorescence VECTASHIELD $^{\circledR}$ H-1000 (Vector Laboratories, Inc. Burlingame, CA). Fluorescence was observed on a Zeiss Axiovert 200M microscope (Carl Zeiss, Oberkochen, Germany).

The specificity of the immunofluorescent staining was assessed for each experimental condition by performing the reaction in the absence of primary antibodies. No staining was observed under such conditions.

\section{TOTAL RNA EXTRACTION AND RT-PCR}

The expression of the pluripotency markers (OCT3/4, NANOG, SOX-2 and KLF-4) and ion channels subunits genes (KCNQ1,Kv4.2, Cal $\alpha$ and SCN5A and gap junction protein $C \times 43$ ) transcripts in USP1 cells was analyzed by RT-PCR. Total RNA was extracted from the cells using RNeasy ${ }^{\circledR}$ Mini Kit 
(Qiagen) following manufacturer's instructions. One $\mu \mathrm{g}$ of total RNA was reverse-transcribed into cDNA using random primers and High-Capacity Reverse transcription Kit (Applied Biosystems) following manufacture's instructions. Heart tissue was used for positive control. In addition, a corresponding sample without reverse transcriptase (-RT sample) was included to assess for DNA contamination. Specific forward and reverse primers were designed to span introns and avoid eventual DNA contamination detection. Amplification of $B$-ACTIN mRNA was used as internal control of amplification. The primer sequences and size of expected products are described in Table I. Two $\mu \mathrm{L}$ aliquots of each 10x diluted cDNA samples were amplified in a Peltier Thermal Cycler PTC-200 (MJ Research) in a $50 \mu \mathrm{L}$ reaction mixture containing $1 \mathrm{x}$ PCR Buffer (Invitrogen), $2.5 \mathrm{mM} \mathrm{MgCl}, 0.2 \mathrm{mM}$ of each deoxynucleotide triphosfate (dNTP), $0.2 \mu \mathrm{M}$ of each forward and reverse primer and $1 \mathrm{U}$ of Platinum Taq Polymerase (Invitrogen). The RTPCR program consisted of denaturing at $95^{\circ} \mathrm{C}$ for $5 \mathrm{~min}$., 30 cycles of denaturing at $95^{\circ} \mathrm{C}$ for $1 \mathrm{~min}$., anneling at $56^{\circ} \mathrm{C}$ for $1 \mathrm{~min}$., and extension at $72^{\circ} \mathrm{C}$ for $1 \mathrm{~min}$, followed by a final extension at $72^{\circ} \mathrm{C}$ for $10 \mathrm{~min}$. The RT-PCR products were separated and analyzed on $1.5 \%$ agarose gel stained with ethidium bromide. All amplifications products were subjected to direct sequencing in order to confirm the identity of the PCR product.

ELECTROPHYSIOLOGY

Cells were plated at low density on glass coverslips in culture medium. Before the experiment the cells were transferred to an extracellular solution containing in $\mathrm{mM}$ : $150 \mathrm{NaCl}, 5 \mathrm{KCl}$, $1 \mathrm{MgCl} 2$ and $10 \mathrm{Na}-4$ - (2hydroxyethyl)-1piperazineethanesulfonic acid (HEPES), pH 7.4. Voltage clamp was performed using the conventional whole-cell patch-clamp technique. All experiments were performed at room temperature $\left(22-25^{\circ} \mathrm{C}\right)$, and all tested drugs were added to the external bath solution, which was continuously perfused at $1 \mathrm{~mL} / \mathrm{min}$ flow rate. Patch electrodes (2-7 M $)$ were prepared from borosilicate glass pipettes on a two-stage pipette puller (Sutter Instruments, P-97, Novato, USA). Cells were voltage-clamped using a patch-clamp amplifier Axopatch 200 (Axon Instrument, Inc., Sunnyvale, USA), and the signal was filtered through an 8-pole Bessel low-pass filter (Frequency Devices, Haverhill, USA) with 1 $\mathrm{kHz}$ cut-off frequency. Currents were sampled at a frequency of $2.5 \mathrm{kHz}$ using an analogue-to-digital converter (DIGIDATA 1200, Axon Instrument, Inc., Sunnyvale, USA) connected to a PC compatible computer. Voltage-clamp protocols were generated by the pCLAMP software 10.1 (Axon Instrument, Inc., Sunnyvale, USA). To record currents, a protocol was applied every $6 \mathrm{~s}$ from the holding potential $-70 \mathrm{mV}$ to test potentials that varied from -80 to $+100 \mathrm{mV}$, in $10 \mathrm{mV}$ increments, for $2.5 \mathrm{~s}$ or $500 \mathrm{~ms}$. To investigate the presence of calcium current (ICa) or sodium current (INa), a protocol was applied every $6 \mathrm{~s}$ from the holding potential $(-70 \mathrm{mV})$ to test potentials that varied from -60 to $+60 \mathrm{mV}$, in $10 \mathrm{mV}$ increments, for $500 \mathrm{~ms}$. Solutions and reagents: Control Tyrode's solution contained (in millimolar): $150.8 \mathrm{NaCl}$, $5.4 \mathrm{KCl}, 1.8 \mathrm{CaCl}_{2}, 1.0 \mathrm{MgCl}_{2}, 11.0 \mathrm{D}$-glucose, 10.0 HEPES, and $\mathrm{pH} 7.4$ adjusted with $\mathrm{NaOH}$. The slowly delayed rectifier outward potassium current (IKs) was recorded with an internal pipette solution containing (in millimolar): $15.0 \mathrm{KCl}, 119$ potassium glutamate, $3.75 \mathrm{MgCl}_{2}, 0.5 \mathrm{CaCl}_{2}, 5.0$ EGTA, 5.0 HEPES, and 2.8 ATP; pH adjusted to 7.2 with $\mathrm{KOH}$. External solution was Tyrode with nicardipine $(1 \mu \mathrm{M})$, to block calcium current and E-4031 $(5 \mu \mathrm{M})$ to block IKr (Medei et al. 2008). The transient outward potassium current (Ito) was elicited in external Tyrode' solution with nicardipine $(1 \mu \mathrm{M})$ to block calcium current. The internal solution contained (in millimolar): 50.0 $\mathrm{KCl}, 1.0 \mathrm{MgSO}_{4}, 10.0$ EGTA, 80.0 L-aspartic acid, 
10.0 $\mathrm{KH}_{2} \mathrm{PO}_{4}, 5.0$ HEPES, and 3.0 ATP $(\mathrm{Na}+) ; \mathrm{pH}$ adjusted to 7.2 with $\mathrm{KOH}$. To record the $\mathrm{ICa}$ and $\mathrm{INa}$, the internal solution contained (in millimolar): $110 \mathrm{CsCl}, 30$ TEA-Cl, 5 MgATP, 0.1 GTP, 10 HEPES, and 10 EGTA (pH adjusted to 7.1 with $\mathrm{CsOH}$ ). To eliminate ion currents other than $\mathrm{ICa}$, once whole-cell recording was achieved, the bath solution was switched to an extracellular solution containing tetraethylammonium (TEA) - cesium (Cs) solution (Silva et al. 2010), in which $\mathrm{Na}$ was substituted by TEA and $\mathrm{K}$ was replaced by $\mathrm{Cs}$ containing (in millimolar) 140 TEA-Cl, 6 CsCl, 1 $\mathrm{MgCl}_{2}, 2 \mathrm{CaCl}_{2}, 11$ glucose, and 10 HEPES (pH adjusted to 7.3 with TEA-OH).

\section{DYE TRANSFER}

Confluent cultures of inactivated MEF (MEFi), co-cultures of mESC and MEFi or mESC and cardiomyocytes plated on $35 \mathrm{~mm}$ Petri dishes, were injected with Lucifer Yellow (LY) CH (5\% in 150 $\mathrm{mM} \mathrm{LiCl}$ ) (457.2 Da) using glass microelectrodes (resistance between 40-70 $\mathrm{M} \Omega$ ) by the application of short hyperpolarizing current pulses $(0.1 \mathrm{nA}, 100$ milliseconds using a WPI amplifier, model 7060; USA). Fluorescence was observed on an Axiovert 100 microscope (Carl Zeiss, Oberkochen, Germany) equipped with appropriate filters (Zeiss BP450490 / FT510 / LP520) and photographs were taken using the software Image Pro, 1 to $15 \mathrm{~min}$. after dye injection. To measure the degree of coupling under culture conditions where only MEFi or MEFi and mESC were present, a minimum of 90 cells were injected in at least three independent experiments. Coupling degree was arbitrarily divided into two classes: no coupling (0); or at least one neighbor cell coupled to the cell injected with Lucifer Yellow $(\geq 1)$. In the co-culture model with cardiomyocytes, dye was always injected in the eGFP-cardiomyocyte and we evaluated the presence of heterocelular coupling or absence of coupling in 50 injected cells in at least five independent experiments. Results are presented as mean \pm S.D.

\section{RESULTS}

\section{TRANSCRIPTIONAL ANALYSIS}

As a first approach, we investigated the presence of transcripts related to pluripotency and ion channels subunits in the USP-1 cells. The presence of mRNA for $O C T-3 / 4, S O X-2, N A N O G$ and KLF-4 genes (Fig. 1A) confirmed, as expected, the pluripotent state of USP-1 mESC, previously established by the ability of the cell line to form chimeras (Sukoyan et al. 2002). RT-PCR also detected mRNA for $K C N Q 1, K v 4.2, C a-\alpha-1 c$ and $C x 43$ genes but did not detect transcripts for SCN5A (Fig. 1B) that correspond to sodium alpha subunit gene that codifies Nav1.5 a voltage-gated sodium channel. The same transcripts were analyzed in extracts of heart, as positive controls, and in pure cultures of MEF, since these cells are used as feeder layers for the mESC and therefore could contaminate the PCR results. Only $C \times 43$ and the internal control $B$-ACTIN transcripts were detected in MEF cultures. This first set of experiments gave us insight into which proteins might be present in the mESC in their undifferentiated state.

\section{Morphology of CELl CUlture AND LoCALIZATION OF MOLECULES}

The second step was to localize the proteins in the cells, thus confirming that the mRNA was being translated. USP-1 mESC are small and spherical, as previously described (Evans and Kaufman 1981, Martin 1981, Sukoyan et al. 2002), and quite distinct from MEF, which are large and flat (Fig. 2A). The positive immunoreactivity for OCT-3/4 and SSEA-1 (Fig. 2B), confirmed the pluripotent state of these cells. The presence and localization of connexins in these cells was investigated by immunofluorescence for $\mathrm{Cx} 43, \mathrm{Cx} 45$ and $\mathrm{Cx} 32$. In consonance to RT-PCR experiments, $\mathrm{Cx} 43$ was observed in undifferentiated USP-1 colonies as evidenced by double labeling with SSEA-1 expression (Fig. 2C). 


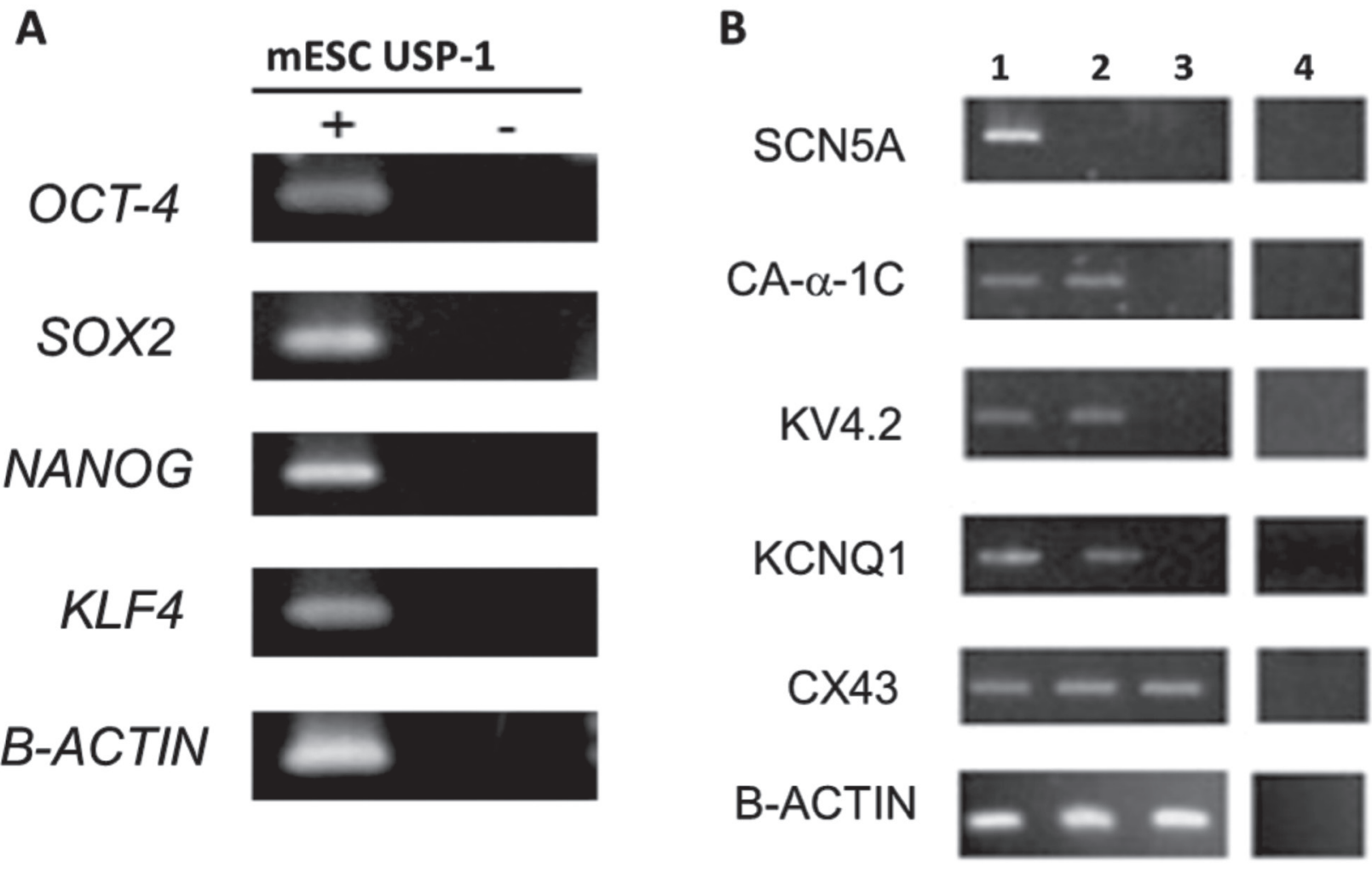

Figure 1 - Transcriptional analysis of mESC. A: RT-PCR products of the pluripotent related transcripts of genes. The RT $(+)$ and (-) samples refer to amplification of RNA in the presence and absence of reverse transcriptase, respectively. Amplification of b-actin transcript was used as the internal control; B: RT-PCR products of the genes coding for ion channels. These cells were used for total RNA extraction and RT-PCR amplification as described in methods. Lane 1: Heart (positive control), lane 2: USP-1, lane 3: MEF and lane 4: amplification of RNA in the absence of reverse transcriptase. Amplification of $\beta$-actin transcript was used as the internal control. Both analyzed on a $1.5 \%$ agarose gel electrophoresis and visualized by ethidium bromide staining.

Immunofluorescence confirmed the expression of KCNQ1 (Fig. 2D), Kv4.2 (Fig. 2E) and the $\alpha$-subunit of the calcium channel Ca1 $\alpha$ (Fig. 2F). In addition two other potassium channel proteins were detected, Kv1.4 and Kv4.3. In combination with Kv4.2 these proteins are responsible for forming the channel of the so-called transient outward potassium current (Ito). As expected from RT-PCR data (negative expression of SCN5A gene), immunofluorescence for Nav1.5, which codifies for alpha subunit protein that form the sodium voltage-gated channel, did not detect protein.

ELECTROPHYSIOLOGICAL PROPERTIES

After checking for the presence of transcripts and proteins, we investigated whether the expressed proteins are functional using whole cell patch clamp and intracellular injection of fluorescent dyes.

Electrophysiological recordings were performed in 41 undifferentiated mESC of the USP-1 line. Of these, in 33 cells we used pulse protocols that allowed for the investigation of the presence of potassium currents. A total of 19 (57.6\%) showed a superposition of two potassium currents with different kinetics: one with slow activation kinetics and rectification, probably representing the delayed type of potassium current known as Ik, and another with fast activation and inactivation, consistent with the transient potassium current, known as Ito. Other 14 cells showed only the profile of activation with slow delayed rectification (42.4\%). Lastly, 8 cells 

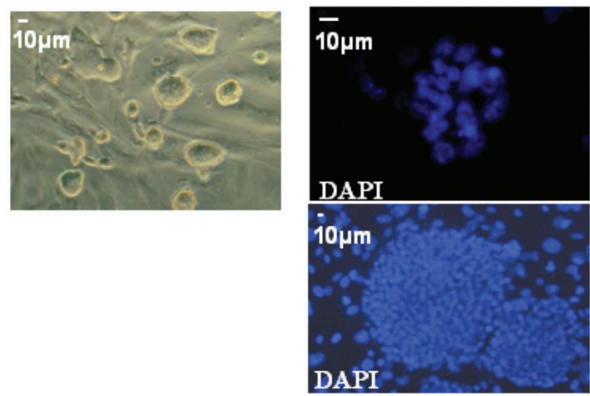

C
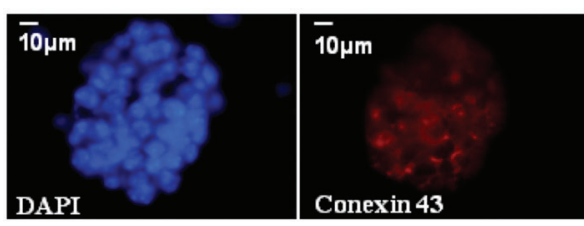
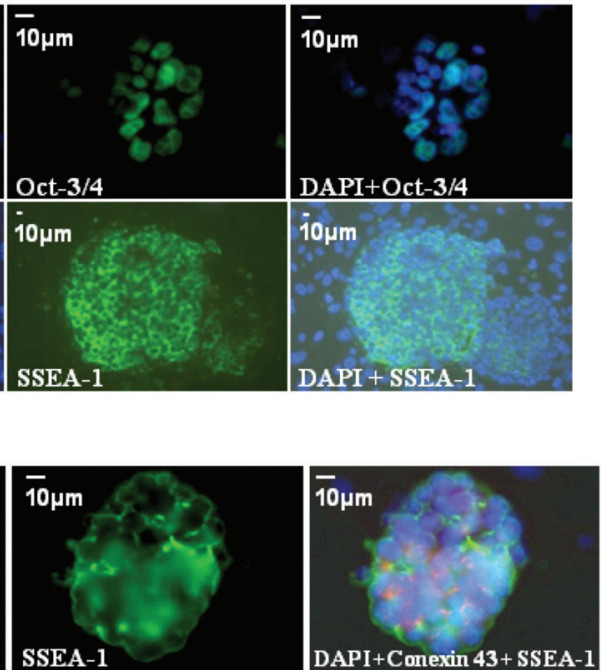

D
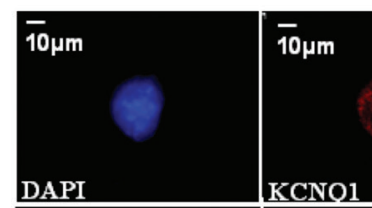

SSEA-1

DAPI+Conexin $43+$ SSEA-1

E

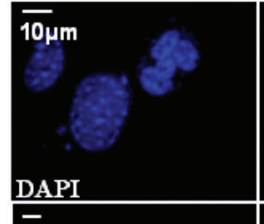

$\overline{10} \mathrm{~mm}$
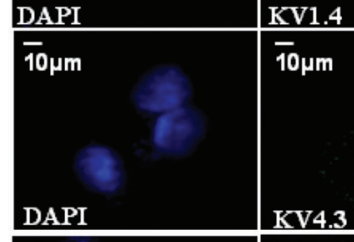

$\overline{10} \mu \mathrm{m}$

$\overline{10} \mu \mathrm{m}$

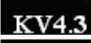

$\overline{10}$ um

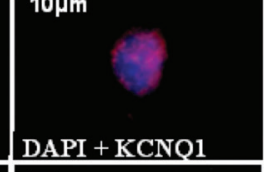

$\overline{10 \mu m}$

$10 \mu \mathrm{m}$

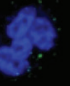

.

DAPI + KV1.4

$\overline{10} \mu \mathrm{m}$

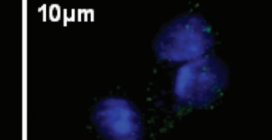

DAPI + KV4.3

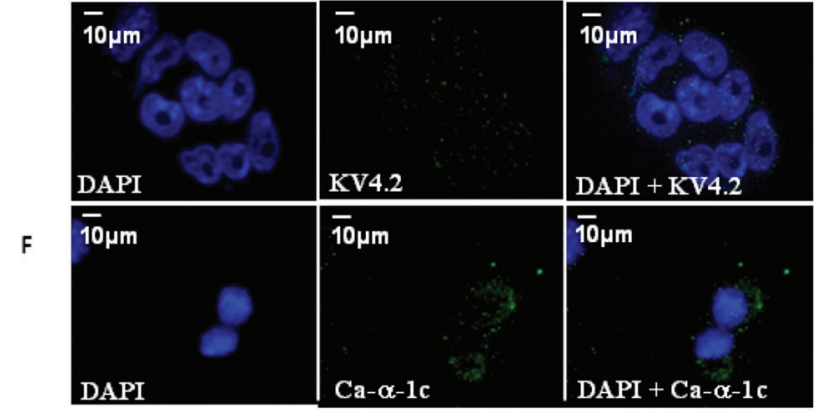

Figure 2 - Morphology of cell culture and localization of molecules. A: Morphology of undifferentiated mESC in phase contrast (original magnification 320X); B: Immunofluorescence of pluripotency markers protein. Top line, DAPI (left), Oct-3/4 (middle) and merge images (right) (original magnification 630X). Line below, DAPI (left), Oct-3/4 (middle) and merge images (right) (original magnification 200X); C: immunofluorescence against Cx43 and surface protein SSEA -1 in undifferentiated mESC. Nuclei stained with DAPI (left), Gap junction protein Connexin43 and SSEA -1 (middle) and merge of C images (right) (original magnification 630X); D: immunofluorescence of $\alpha$ sub-unit of IKs ion current channel: DAPI (left), KCNQ1 (middle) and merge images (right)(original magnification 1000X); E: shows three $\alpha$ sub-units of $\mathrm{I}_{\text {to }}$ ion current channel, $\mathrm{Kv} 1.4, \mathrm{Kv} 4.3 \mathrm{and} \mathrm{Kv}$ 4.2. DAPI (left), $\alpha$ sub-units (midle) and merged images (right) (original magnification 630X). Finally, (F) $\alpha$ sub-unit of L-type Calcium ion current channel was detected, DAPI (left), Ca- $\alpha-1 \mathrm{c}$ (middle) and merge images (right) (original magnification 630X). 
were used for specific protocols in order to investigate the presence of calcium or sodium currents.

Membrane capacitance for the USP-1 cells was $48.7 \pm 4 \mathrm{pF}(\mathrm{n}=14)$. To assess whether undifferentiated USP-1 express functional voltagegated channels, voltage steps ( $2.5 \mathrm{~s}$ duration) were applied to the patched cells held at $-70 \mathrm{mV}$, driving the membrane potential from -80 to $+100 \mathrm{mV}$. The first records were obtained without any pharmacological intervention, thus we could only observe outward currents (Fig. 3A, left). As shown in Figure 3A (middle) when a potassium channel blocker, Barium Chloride $(5 \mathrm{mM})$, was added to the bath solution, the outward current decreased significantly and the effect was reversible (Fig. 3A, right), suggesting that potassium was the current carrying ion.

To test for the presence of Iks in this outward current, we used a specific IKs blocker, chromanol293B. In the presence of the blocker, current intensity decreased by half (Fig. 3B). In some cells, another potassium current had kinetic and voltage response compatible with Ito, exhibiting a component of fast activation and inactivation, typical of this type of channel (Fig. 3C, left). To test for the presence of Ito we changed the duration of the voltage steps to 500 ms and performed a pharmacological intervention using a drug known to inhibit Ito, 4-amino-pyridine (4-AP) (Medei et al. 2008). After 4-AP, current intensity also decreased (Fig. 3C, middle), as observed in the I/V curve (Fig. 3C, right).

In none of these recordings we were able to detected inward currents; however this could be due to these currents being masked by the greater intensity of the outward currents. To test for the presence of inward currents, we removed the calcium from the bathing solution and replaced it with barium chloride, as this ion also permeates the calcium channel, amplifies the inward current and blocks outward ones. Our data show that USP-1 do not exhibit any inward currents (Fig. 3D). It is possible that calcium channels are not functional in undifferentiated USP-1 cells, although the protein is present in the cell.
In our culture system, we have three possible types of coupling between cells, the homocelular, when mESC communicate with each other, and heterocellular, when mESC communicate with cardiomyocytes or with MEF (Fig. 4A). Intracellular dye injection in USP-1 colonies showed that confluent cultures of USP-1 display significant coupling. In Figure 4B, the diffusion of the dye was followed for $15 \mathrm{~min}$ and the 2 colonies injected were fully labeled by the dye. However, we could not see dye passage to any MEFi. We did not observe heterocellular coupling between MEFi and mESC, when either cell types were injected with the dye, but homocellular coupling was present in both cell types. Additionally, these cells were simultaneously injected with Lucifer Yellow (LY), a gap junction permeable dye, and with rhodaminedextran, a 40-kDa molecule that does not permeate through gap-junction channels (Fortes et al. 2004). Only LY spread to the neighboring cells discarding the presence of intercellular bridges (data not shown). Quantitative analyses of LY-injected cells show that $93.3 \%$ of $\mathrm{mESC}$ were coupled to at least one cell, with the number of coupled cells ranging from one to seven cells ( $40 \%$ of injected cells were coupled to three other cells $1 \mathrm{~min}$ after injection), whereas in MEFs only $37.8 \%$ were coupled to at least one neighbor $(24.5 \%$ of injected cells were coupled to one other cell $1 \mathrm{~min}$. after injection). When this analysis was performed in MEF not inactivated, $54.5 \%$ of cells were coupled to at least one neighbor $(36.7 \%$ of injected cells were coupled to one other cell $1 \mathrm{~min}$. after injection). Data on cellular coupling is shown in Figure 4C.

An important challenge for the use of stem cells in myocardial regeneration is the need to form electromechanical connections with host cardiomyocytes, thus promoting engraftment of the exogenous cells. The presence of gap junctions between mESC and the surrounding cardiac myocytes has already been shown in vivo (Thomson et al. 1998) but functional assays, in vitro, have 
A
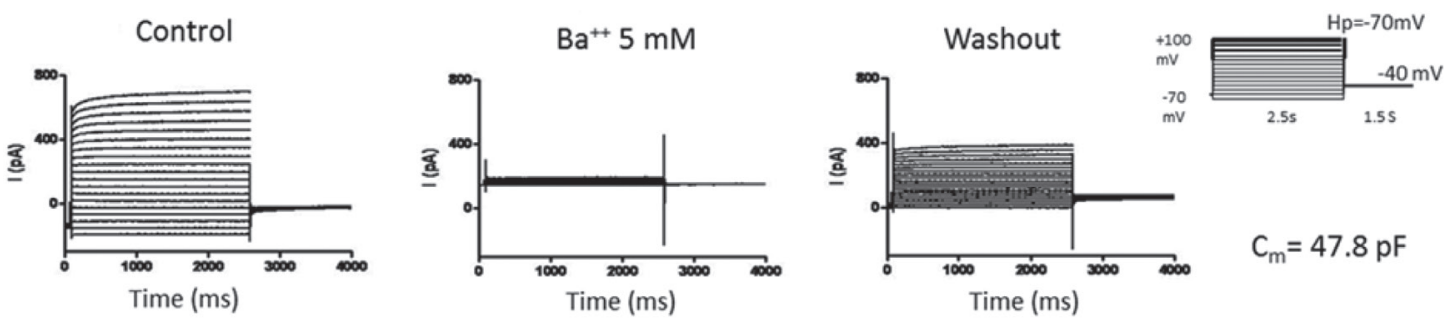

B
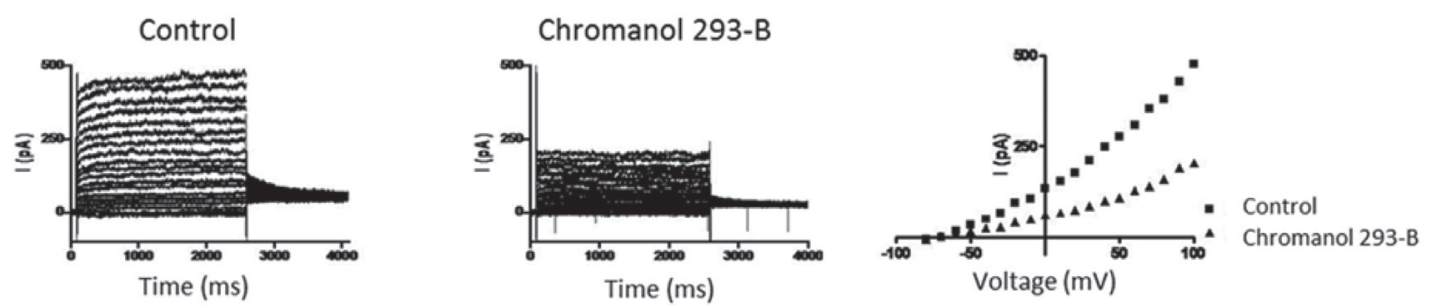

C
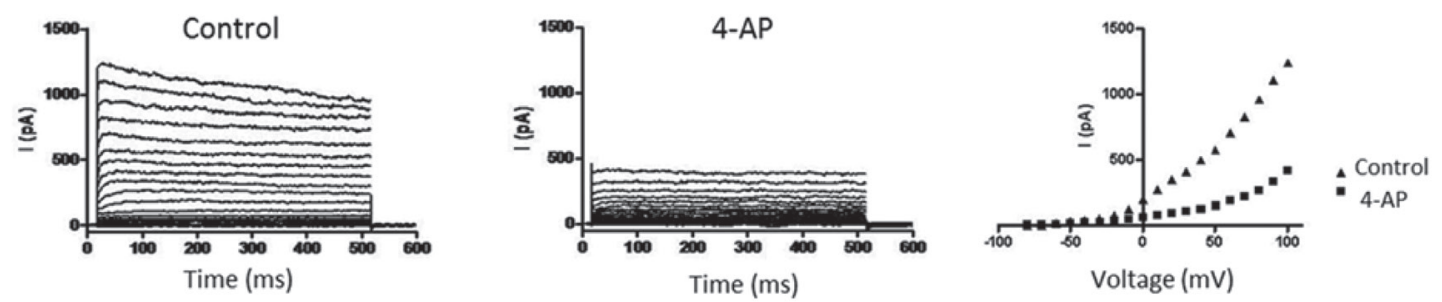

D
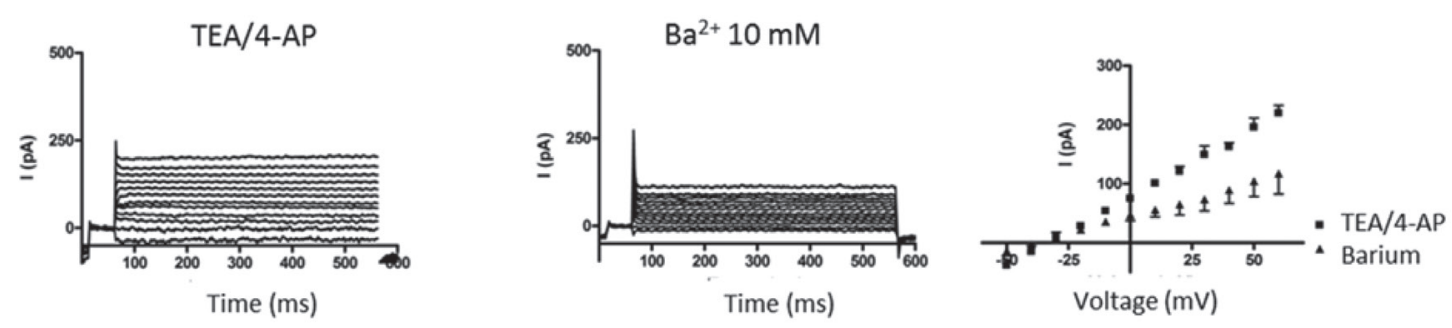

Figure 3 - Voltage-activated currents. A: whole cell voltage activated currents recorded in modified Tyrode's solution (left). Blocking effect of Barium $5 \mathrm{mM}$ (middle) on outward rectifying currents is reversible after washout (right) (n=14); B: effect of Chromanol 293B on outward rectifying currents blocker. Family of currents recorded on a cell bathed in modified Tyrode's solution without or with Chromanol 293-B (left and middle). Right shows current-voltage relationship (I-V) in absence ( $\mathbf{\square})$ or presence of Chromanol 293-B $(\boldsymbol{\Delta})$; C: effect of 4-AP (5 mM) on fast inactivating outward currents. Family of currents recorded on a cell bathed in modified Tyrode's solution without (left) or with 4-AP (middle). Right figure shows current-voltage relationship (I-V) in absence ( $\boldsymbol{\Delta}$ ) or presence of 4-AP (ש). Currents were elicited by depolarizing steps from $\mathrm{Vh}=-70 \mathrm{mV}$ to potentials ranging from $-80 \mathrm{mV}$ to $+100 \mathrm{mV}$; $\mathrm{D}$ : voltageactivated barium currents were recorded on a cell bathed in modified Tyrode's solution contained TEA (10 mM) and 4-AP (5 mM) without (left) or with $10 \mathrm{mM} \mathrm{BaCl}_{2}$ (middle). Right figure shows current-voltage relationship in absence ( $\left.\mathbf{\square}\right)$ or presence of $\mathrm{BaCl}_{2}(\mathbf{\Delta})$. Cells were maintained at a holding potential of $-70 \mathrm{mV}$ and stepped from $-60 \mathrm{mV}$ to $+60 \mathrm{mV}$ in $10 \mathrm{mV}$ increments for $500 \mathrm{~ms}$. 


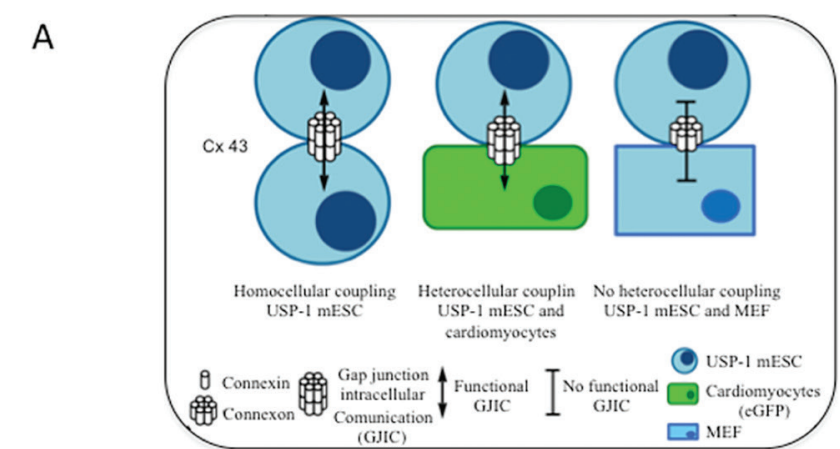

B
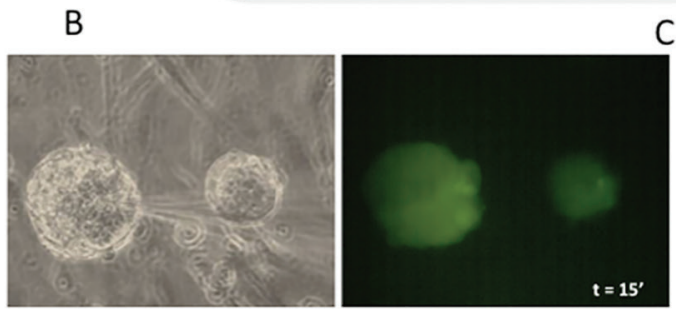
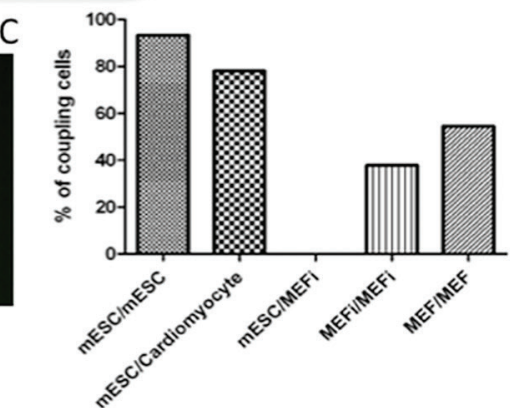
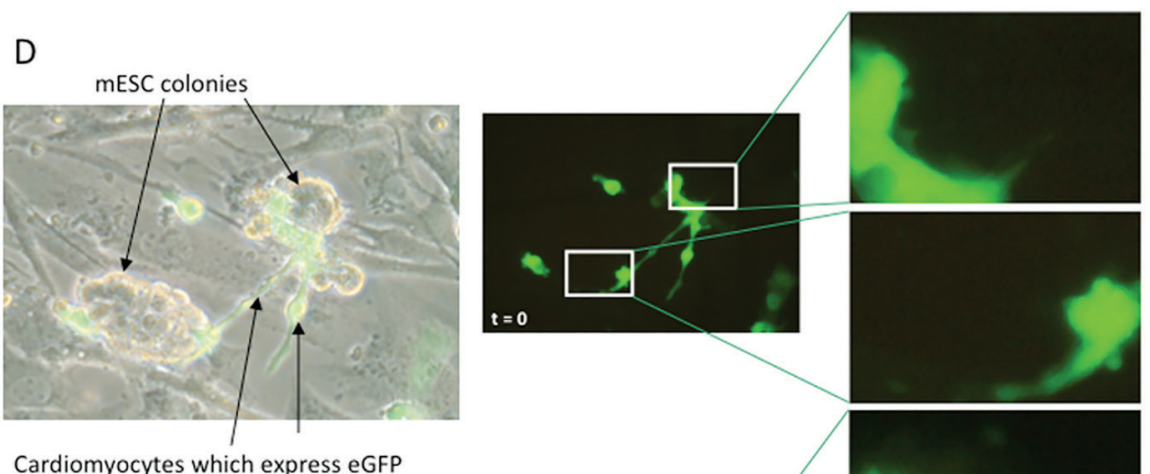

Cardiomyocytes which express eGFP
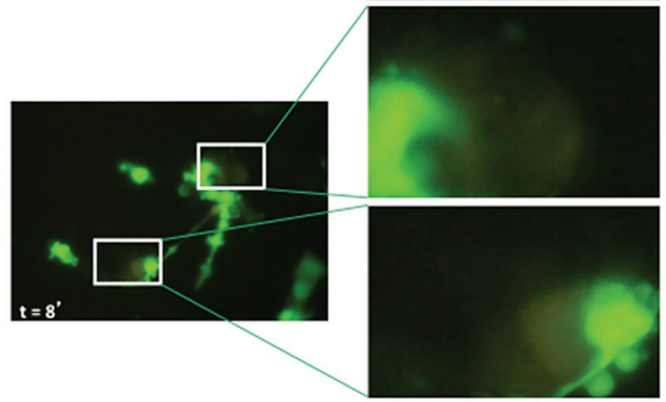

Figure 4 - Presence of functional coupling among undifferentiated mESC and cardiac cells. Dye coupling was assayed through intracellular injection of Lucifer Yellow (LY) by hyperpolarizing currents pulses. A: illustration summarizes the possible couplings investigated with mESC; B: a representative figure of two colonies injected with LY; phase contrast (left) and Fluorescence (right) show that the dye spreads to the whole colony (original magnification $320 \mathrm{X})$; C: the bar graphs summarize the data of cellular coupling analyzed; D: co-culture model of mESC and cardiomyocyte $\mathrm{GFP}^{+}$. Phase contrast and fluorescence of $\mathrm{GFP}^{+}$merged images (left). Functional hetero-cellular coupling. In the middle, the pictures show two different times of dye injection, just before injection ( $\mathrm{t}=0$ ) and 8 minutes after dye injection, and on the right, details of coupling among cardiomyocytes and mESC (original magnification 320X). 
not yet been performed. In order to address this issue we analyzed the presence of functional GJIC between USP-1 and $\mathrm{eGFP}^{+}$-cardiomyocytes in coculture (Fig. 4D, phase contrast at left) using Lucifer Yellow. LY was always injected into spontaneously contracting eGFP+ cardiomyocytes. Dye transfer was observed in 39 out of 50 (78\%) injected cells indicating that functional coupling through gap junctions between USP-1 and the neighboring cardiomyocytes was present. Fluorescence in Figure 4D shows a temporal sequence of photomicrographs, where the first passage of the dye from the eGFPcardiomyocytes to the colonies of USP-1 can be seen after $2 \mathrm{~min}$. and then the gradual change of color in the colonies of $\mathrm{mESC}$ is followed for up to 8 min.. Details show the mESC colonies before and eight minutes after injection of dye, indicating that cells of both colonies were stained.

\section{DISCUSSION}

In this paper, we demonstrate that USP-1 mouse embryonic stem cells express the transcription factors related to pluripotency (OCT-3/4, Sox-2, Nanog and Klf4), with OCT-3/4 and SSEA-1 proteins located in these cells by immunofluorescence. These results corroborate with other studies, either using USP-1 or other kinds of mESC, confirming the undifferentiated state of mESC (Evans and Kaufman 1981, Martin 1981, Sukoyan et al. 2002, Thomson et al. 1998, Pesce et al. 1999, Mitsui et al. 2003, Chambers et al. 2003, Solter and Knowles 1978).

Wörsdörfer et al. (2008) reported that the expression of $\mathrm{Cx} 43$ in HM1 mESC line is high. In addition, the same group demonstrated that the coupling of mESC derived from $\mathrm{Cx} 43$-deficient animal was decreased when compared with wild-type ESC, suggesting that $\mathrm{Cx} 43$ has an important impact on cell-cell coupling in mESC. Here we observed transcripts and protein for $\mathrm{Cx} 43$. These results corroborate the data reported by Oyamada et al. 1996. Although not found in USP-1 mESC, Davies et al. 1996 has described the mRNA expression of other connexin proteins, such as $30.3,31,31.1,40$, and 45 in other mESC strain. In this direction, Wong et al. 2004 shows, the functional presence of $\mathrm{Cx} 45$ in two different hESC lines (HES3 and HES4).

The cell-cell coupling between ESC and cardiomyocytes have been observed by several groups using the model of co-culture seeding rats cardiomyocytes and different sources of stem cells (Ramkisoensing et al. 2011, Bollini et al. 2011, Valarmathi et al. 2011, Rastan et al. 2005, Garbade et al. 2005). Here we used the co-culture with mouse eGPF-cardiomyocytes and USP-1 mESC to test the hypothesis whether both types of cells are able to make functional GJIC. Thus, homocellular coupling in USP-1 mESC and heterocellular coupling between USP-1 mESC and cardiomyocytes was observed. Although Cx43 transcripts were detected in MEF cultures, our data showed no heterocellular coupling between USP-1 mESC and MEF. This result corroborates with other studies reporting that hESC coupling to MEF is extremely rare or absent (Huettner et al. 2006, Wong et al. 2006).

A large percentage of USP-1 mESC tested, expressed both Iks and Ito potassium currents while a smaller percentage exhibited only the Iks potassium current. This observation parallels the heterogeneous pattern of ion channel expression described by Wang et al. (2005) for mESC and hESC, and for human mesenchymal stem cells by Heubach et al. (2004). As described by other authors, the transcript expression profile of mESCs does not always correspond to the functional expression profile of ion channels. Van der Heyden et al. (2003) demonstrated that a variety of ion channel transcripts, such as those for Kv4.3, KCNQ1, SCN5A, and cyclic nucleotidegated channel $(\mathrm{HCN})$, are present in pluripotent mESCs, but no ionic currents could be detected electrophysiologically before differentiation was induced (Van Kempen et al. 2003). Similarly, a direct correlation between mRNA expression and measurable membrane ionic currents is also not 
seen in the pluripotent P19 embryonic carcinoma cell line (Van Kempen et al. 2003). In the present study, functional potassium channels were detected, but no calcium current was found, although the transcript and the protein for calcium channel were identified in $\mathrm{mESC}$.

In conclusion here we observed that USP-1 mESC show the classical pluripotent markers, have functional Cx43 enhancing GJIC among themselves and with cardiomyocytes but not with MEF, and have an electrophysiological profile similar to that described by other mESC or hESC cell lines, expressing potassium channels.

\section{ACKNOWLEDGMENTS}

The authors are thankful to Professor Lygia Pereira (University of São Paulo, Brazil) who kindly provided the mESC-USP-1, the first Brazilian derived mESC cell line. This work was funded by grants from the Conselho Nacional de Desenvolvimento Científico e Tecnológico (CNPq), Coordenação de Aperfeiçoamento de Pessoal de Nível Superior (CAPES), Fundação Carlos Chagas Filho de Amparo à Pesquisa do Estado do Rio de Janeiro (FAPERJ) and Departamento de Ciência e Tecnologia (DECIT Ministério da Saúde) Brazil. The authors declare no conflicts of interest.

\section{ABBREVIATION LIST}

4-AP: 4-amino-pyridine

Cx43: connexin 43

Cy3: Cyanine Dye 3

DAPI: diamidino-2-phenylindole dye

eGFP: enhanced Green Fluorescent Protein

ESC: Embryonic stem cells

GJIC: gap junction intercellular communication

HEPES: 4 - (2hydroxyethyl)-1-piperazineethanesulfonic acid

hESC: human ESC

$\mathrm{ICa}^{++}:$calcium current

Ikr: rapid delayed rectifier outward potassium current Iks: slowly delayed rectifier outward potassium current
INa: sodium current

iPSC: induced pluripotent stem cells

Ito: transient outward potassium current

KCND2: transient outward potassium channel subunits gene

KCNQ1: delayed rectifier outward potassium channel subunit 1 gene

Kv1.4, 4.2 or 4.3: voltage-gated transient outward potassium channel subunits

Nav1.5: voltage-gated sodium channel

LIF: leukaemia inhibitory factor

LY: Lucifer Yellow

MEF: mouse embryonic fibroblasts

MEFi: inactivated MEF

mESC: mouse embryonic stem cells

OCT-3/4: octamer-binding transcription factor 4

PBS: phosphate-buffered saline

SCN5A: sodium voltage channel alpha subunit gene SSEA-1: stage-specific Embryonic antigen 1

TEA: tetraethylammonium

USP-1: Brazilian derived mESC

\section{RESUMO}

As linhagens de células tronco pluripotente embrionárias de camundongos (mESC) são derivadas da massa celular interna de blastocistos da fase inicial dos embriões. Como diferentes trabalhos têm demonstrado que a modulação dos canais iônicos pode interferir tanto no crescimento como no processo de diferenciação das células tronco embrionárias, tanto humanas como de camundongos, é importante caracterizar as propriedades eletrofisiológicas de novas mESC e compará-las com outras linhagens preestabelecidas. Neste trabalho, estudamos a comunicação intercelular através de junções comunicantes em mESC (USP-1, derivadas no Brasil pelo grupo da Dra. Lygia Pereira) e caracterizamos suas propriedades eletrofisiológicas. Usamos imunofluorescência e RT-PCR para detectar a presença de $\mathrm{Cx} 43$, de marcadores de pluripotência e de canais iônicos. No intuito de avaliar a possível comunicação entre mESC e cardiomiócitos em cocultura, realizamos experimentos de injeção de 
corante, utilizando cardiomiócitos neonatais de rato, onde as células do coração expressavam a proteína verde fluorescente. Os experimentos de patch-clamp, usando bloqueadores específicos, mostrou a presença de dois tipos de correntes de saída de potássio, uma transiente (Ito) e outra retificadora tardia de ativação lenta (Iks). Não observamos correntes de cálcio ou de sódio nas $\mathrm{mESC}$ indiferenciadas. Com estes resultados concluímos que a linhagem mESC USP-1 expressa os marcadores clássicos de pluripotência, tem canais funcionais formados por $\mathrm{Cx} 43$, como demonstrado pela comunicação intercelular tanto entre elas mesmas como com cardiomiócitos, e possui um perfil electrofisiológico semelhante a outras linhagens celulares de mESC.

Palavras-chave: $\mathrm{Cx} 43$, propriedades eletrofisiológicas, junções comunicantes, células embrionárias de camundongo.

\section{REFERENCES}

BHATTACHARYA B ET AL. 2004. Gene expression in human embryonic stem cell lines: Unique molecular signature. Blood 103: 2956-2964.

Bollini S ET AL. 2011. In Vitro and In Vivo Cardiomyogenic Differentiation of Amniotic Fluid Stem Cells. Stem Cell Rev and Rep 7: 364-380.

CArpenter MK, Rosler ES, Fisk GJ, Brandenberger R, Ares X, Miura T, Lucero M and Rao MS. 2004. Properties of four human embryonic stem cell lines maintained in a feeder-free culture system. Dev Dyn 229: 243-258.

Chambers I, Colby D, Robertson M, Nichols J, LeE S, TweEdIE S AND SMITH A. 2003. Functional expression cloning of Nanog, a pluripotency sustaining factor in embryonic stem cells. Cell 113: 643-655.

DAVIES TC, BARr KJ, JONES DH, ZHU D AND KidDER GM. 1996. Multiple members of the connexin gene family participate in preimplantation development of the mouse. Dev Genet 18(3): 234-243.

EVANS MJ AND KAUFMAN MH. 1981. Establishment in culture of pluripotential cells from mouse embryos. Nature 292: 154-156.

FORTES FSA ET AL. 2004. Modulation of intercellular communication in macrophages: possible interactions between GAP junctions and P2 receptors. J Cell Sci 117: 4717-4726.

Garbade J, Schubert A, Rastan AJ, Lenz D, WALther T, GuMMERT JF, DHEIN S AND MOHR FW. 2005. Fusion of bone marrow-derived stem cells with cardiomyocytes in a heterologous in vitro model. Eur J Cardiothorac Surg 28: 685-691.
Heubach JF, Graf EM, Leutheuser J, Bock M, Balana B, ZAhanich I, Christ T, Boxberger S, Wettwer E AND RAVENS U. 2004. Electrophysiological properties of human mesenchymal stem cells. J Physiol 554: 659672.

HILLE B. 2001. Ion channels of excitable membranes (third ed.). Sunderland, Mass: Sinauer Associates.

HuetTNER JE, Lu A, Qu Y, Wu V, Kim M AND MCDONALD JW. 2006. Gap Junctions and Connexon Hemichannels in Human Embryonic Stem Cells. Stem Cells 24: 16541667.

JiANG P, RUSHING SN, KONG CW, FU J, LIEU DK, CHAN CW, DENG W AND LI RA. 2010. Electrophysiological properties of human induced pluripotent stem cells. Am J Physiol Cell Physiol 298(3): C486-495.

LeE JB, KIM JM, KIM SJ, PARK JH, Hong SH, RoH S, KIM MK AND YoON HS. 2005. Comparative Characteristics of Three human Embryonic Stem Cell Lines. Mol Cells 19(1): 31-38.

MARTIN GR. 1981. Isolation of a pluripotent cell line from early mouse embryos cultured in medium conditioned by teratocarcinoma stem cells. Proc Natl Acad Sci USA 78: 7634-7638.

MedEI E ET AL. 2008. Antibodies with beta-adrenergic activity from chronic chagasic patients modulate the QT interval and $\mathrm{M}$ cell action potential duration. Europace 10: 868876.

Mitsui K, Tokuzawa Y, Itoh H, SEgawa K, Murakami M, TAKAHASHI K, MARUYAMA M, MAEDA M AND YAMANAKA S. 2003. The homeoprotein Nanog is required for maintenance of pluripotency in mouse epiblast and ES cells. Cell 113: 631-642.

Morokuma J, Blackiston D, Adams DS, SeEbohm G, TRIMMER B AND LEVIN M. 2008. Modulation of potassium channel function confers a hyperproliferative invasive phenotype on embryonic stem cells. Proc Natl Acad Sci USA 105(43): 16608-16613.

OYAMADA Y, KOMATSU K, KIMURA H, MORI M AND OYAMADA M. 1996. Differential regulation of gap junction protein (connexin) genes during cardiomyocytic differentiation of mouse embryonic stem cells in vitro. Exp Cell Res 229: 318-326.

Pesce M, Anastassiadis K And Schoeler HR. 1999. OCT-4: lessons of totipotency from embryonic stem cells. Cells Tissues Organs 165: 144-152.

RAMKISOENSING AA ET AL. 2011. Human embryonic and fetal mesenchymal stem cells differentiate toward three different cardiac lineages in contrast to their adult counterparts. PLoS One 6(9): e24164.

Rastan AJ, WaLther T, Kostelka M, Garbade J, SCHUberT A, STEIN A, DHEIN S AND MoHR FW. 2005. Morphological, electrophysiological and coupling characteristics of bone marrow-derived mononuclear cells-an in vitro-model. Eur J Cardiothorac Surg 27: 104-110.

RICHARDS M, TAN SP, TAN JH, CHAN WK AND BONGSO A. 2004. The transcriptome profile of human embryonic stem cells as defined by SAGE. Stem Cells 22: 51-64. 
Sartiani L, Bettiol E, Stillitano F, Mugelli A, Cerbai E AND JACONI ME. 2007. Developmental changes in cardiomyocytes differentiated from human embryonic stem cells: a molecular and electrophysiological approach. Stem Cells 25(5): 1136-1144.

SILVA HB ET AL. 2010. Voltage-dependent Calcium and Chloride Currents in S17 Bone Marrow Stromal Cell Line. Cell Physiol 223: 244-251.

SÖHL G AND WILLECKE K. 2003. An update on connexin genes and their nomenclature in mouse and man. Cell Commun Adhes 10: 173-180.

SOlter D AND KNOWLES BB. 1978. Monoclonal antibody defining a stage-specific mouse embryonic antigen (SSEA-1). Proc Natl Acad Sci USA 75: 5565-5569.

SUKOYAN MA, KERKIS AY, MELLO MR, KERKIS IE, VISINTIN JA AND PEREIRA LV. 2002. Establishment of new murine embryonic stem cell lines for the generation of mouse models of human genetic diseases. Braz J Med Biol Res 35(5): 535-542.

THOMSON JA, ITSKOVITZ-ELDOR J, SHAPIRO SS, WAKNITZ MA, SWIERGIEL JJ, MARSHALl VS AND JONES JM. 1998. Embryonic stem cell lines derived from human blastocysts. Science 282: 1145-1147.

VALARMATHI MT, FUSELER JW, GOODWIN RL, DAVIS JM AND POTTS JD. 2011. The mechanical coupling of adult marrow stromal stem cells during cardiac regeneration assessed in a 2-D co-culture model. Biomaterials 32: 2834-2850.
Van Der Heyden MA, VAn Kempen MJ, Tsuj Y, RoOK MB, JONGSMA HJ AND OPTHOF T. 2003. P19 embryonal carcinoma cells: a suitable model system for cardiac electrophysiological differentiation at the molecular and functional level. Cardiovasc Res 58: 410-422.

VAN KEMPEN MJA, VAN GINNEKEN A, DE GRIJS I, MUTSAERS N, OPTHOF T, JONGSMA H AND VAN DER HEYDEN M. 2003. Expression of the electrophysiological system during murine embryonic stem cell cardiac differentiation. Cell Physiol Biochem 13: 263-270.

WANG K ET AL. 2005. Electrophysiological properties of pluripotent human and mouse embryonic stem cells. Stem Cells 23(10): 1526-1534.

Wong RC, Pébay A, Nguyen LT, KoH KL And Pera MF 2004. Presence of functional gap junctions in human embryonic stem cells. Stem Cells 22: 883-889.

Wong RCB, DotTori M, KoH KLL, NGUYen LTV, Pera MF AND PÉBAY A. 2006. Gap junctions modulate apoptosis and colony growth of human embryonic stem cells maintained in a serum-free system. Biochem Biophy Res Co 344: 181-188.

WÖrsdörfer P, MaXeiner S, Markopoulos C, Kirfel G, Wulf V, Auth T, Urschel S, Von Maltzahn J AND WILLECKE K. 2008. Connexin expression and functional analysis of gap junctional communication in mouse embryonic stem cells. Stem Cells 26: 431-439. 